medRxiv preprint doi: https://doi.org/10.1101/2020.03.23.20041319; this version posted March 27, 2020. The copyright holder for this preprint (which was not certified by peer review) is the author/funder, who has granted medRxiv a license to display the preprint in perpetuity.

It is made available under a CC-BY-ND 4.0 International license.

\title{
Impact of changing case definitions for COVID-19 on the epidemic curve and transmission parameters in mainland China
}

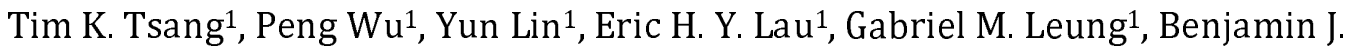

Cowling 1

Affiliation:

1. WHO Collaborating Centre for Infectious Disease Epidemiology and Control, School of Public Health, Li Ka Shing Faculty of Medicine, The University of Hong Kong, Hong Kong Special Administrative Region, China.

\section{Corresponding author:}

Peng Wu, School of Public Health, Li Ka Shing Faculty of Medicine, The University of Hong Kong, 7 Sassoon Road, Pokfulam, Hong Kong

Tel: +852 3917 6746; Email: pengwu@hku.hk

Running head: COVID-19 epidemiology in China

Word count (abstract): 295

Word count (main text): 2,942 
medRxiv preprint doi: https://doi.org/10.1101/2020.03.23.20041319; this version posted March 27, 2020. The copyright holder for this preprint (which was not certified by peer review) is the author/funder, who has granted medRxiv a license to display the preprint in perpetuity.

It is made available under a CC-BY-ND 4.0 International license .

\section{ABSTRACT}

Background: When a new infectious disease emerges, appropriate case definitions are important for clinical diagnosis and also for public health surveillance. Tracking case numbers over time allows us to determine speed of spread and the effectiveness of interventions. Changing case definitions during an epidemic can affect these inferences. Methods: We examined changes in the case definition for COVID-19 in mainland China during the first epidemic wave. We used simple models assuming exponential growth and then exponential decay to estimate how changes in the case definitions affected the numbers of cases reported each day. We then inferred how the epidemic curve would have appeared if the same case definition had been used throughout the epidemic.

Findings: From January through to early March 2020, seven versions of the case definition for COVID-19 were issued by the National Health Commission in China. As of February 20, there were 55,508 confirmed cases reported in mainland China. We estimated that when the case definitions were changed from version 1 to 2 , version 2 to 4 and version 4 to 5 , the proportion of infections being detected as cases were increased by 7.1 -fold (95\% credible interval (CI): 4.8, 10.9), 2.8-fold (95\% CI: 1.9, 4.2) and 4.2-fold (95\% CI: 2.6, 7.3) respectively. If the fifth version of the case definition had been applied throughout the outbreak, we estimated that by February 20 there would have been 232,000 (95\% CI: 161,000, 359,000) confirmed cases.

Interpretation: The case definition was initially narrow, but was gradually broadened to allow detection of more cases as knowledge increased, particularly milder cases and those without epidemiological links to Wuhan or other known cases. This should be taken into account when making inferences on epidemic growth rates and doubling times, and therefore on the reproductive number, to avoid bias. 
medRxiv preprint doi: https://doi.org/10.1101/2020.03.23.20041319; this version posted March 27, 2020. The copyright holder for this preprint (which was not certified by peer review) is the author/funder, who has granted medRxiv a license to display the preprint in perpetuity. It is made available under a CC-BY-ND 4.0 International license.

Funding: Commissioned grant from the Health and Medical Research Fund, Food and Health Bureau, Government of the Hong Kong Special Administrative Region. 
medRxiv preprint doi: https://doi.org/10.1101/2020.03.23.20041319; this version posted March 27, 2020. The copyright holder for this preprint (which was not certified by peer review) is the author/funder, who has granted medRxiv a license to display the preprint in perpetuity.

It is made available under a CC-BY-ND 4.0 International license .

\section{INTRODUCTION}

When a newly emerging infectious disease is first identified, specifying appropriate case definitions can help to identify infected persons in an efficient manner [1]. Often a hierarchy of case definitions will be used, so that a "suspected case" could be defined based on some broad epidemiological and clinical criteria, for example patients with particular exposures or in particular geographic locations, with particular signs or symptoms, at a particular time. A “confirmed case" could be defined as a suspected case in which the pathogen of interest is identified or isolated using a specific laboratory test. Epidemiological and clinical information on patients who meet a case definition can inform the source(s) of infections, potential modes of transmission, transmission dynamics, impact and severity of the infection. All of this information is important for determining the optimal control measures.

COVID-19 is caused by the novel severe acute respiratory syndrome coronavirus 2 (SARS-CoV-2). It was first identified in a cluster of patients with atypical pneumonia in Wuhan in December 2019 [2]. Some of the patients had epidemiological links to the Huanan Seafood Wholesale Market in central Wuhan, and evidence provided by local health authorities suggested that most infections were from a zoonotic source with a limited amount of onwards human-to-human transmission [3]. During the latter part of January 2020 it became clear that infection was spreading efficiently from person to person, and then also that there was a broader clinical spectrum of infections [4]. As a consequence of the evolving information on epidemiological and clinical spectrum of infections, there have been a number of revisions to the case definition for COVID-19 in mainland China. 
medRxiv preprint doi: https://doi.org/10.1101/2020.03.23.20041319; this version posted March 27, 2020. The copyright holder for this preprint (which was not certified by peer review) is the author/funder, who has granted medRxiv a license to display the preprint in perpetuity.

It is made available under a CC-BY-ND 4.0 International license .

Here, we reviewed the various COVID-19 case definitions that have been used in mainland China as of 13 March 2020, and we examined the implications of changes in case definitions on our understanding of the epidemiology of COVID-19.

\section{METHODS}

\section{Sources of data}

We obtained the guidelines on diagnosis and treatment of COVID-19. The first two editions have not been released publicly while the third edition onwards have been released by the National Health Commission [5]. All of the original guidelines were published in Chinese as official government documents, and were translated into English by two authors (PW and YL). Epidemic curves by onset date and report date from December 2, 2019 to February 20, 2020 in China were extracted from the figures presented in the report of the WHO-China Joint Mission in February 2020 [6].

\section{Statistical analysis}

We reviewed the various case definitions and highlighted the key changes in sequential updates. We fitted an exponential growth model to the incidence of cases to quantify the effect of changing case definitions on the epidemic curve. In the model, we assumed that each change in case definition increased the proportion of cases that would be detected among all infections. To account for the control measures, such as the lockdown in Wuhan and other cities in China on January 23, 2020 and the subsequent days [7], we allowed the growth rate to change on January 23. Because the interventions acted to prevent infections but the epidemic curve was based on date of symptom onset in our analysis, the effect of the interventions would be expected to have a slightly delayed effect on the epidemic curve which we accounted for by incorporating the incubation 
period distribution. The incubation period was assumed to follow a log-normal distribution with mean 5.2 days and standard deviation 3.9 days [8].

When changing the case definition, there could be a backfill of cases that fulfilled the new case definition around the change time. We allowed for backfill up to 10 days before each change in case definitions by assuming that a change in case definitions may have a partial effect on incidence before the change date $t$. For each day $k$ before the change date $t$, this partial effect was assumed to be the probability that the cases at day $k$ would be reported at or after the change date $t$. We assumed this onset-to-reporting distribution followed a Gamma distribution and inferred this distribution from the time series of onset and reporting in China by using the convolution of the symptom onset time series and the onset-to-reporting distribution to compute the expected number of reported cases for each day in the epidemic. Then we used a normal likelihood to the logarithm of observed and expected time series of cases by reporting date. We estimated the growth rate as one of the model parameters, and we estimated the doubling time by $\log (2)$ divided by the estimated growth rate. We fitted separate models for (1) Wuhan, (2) Hubei province excluding Wuhan, and (3) the rest of mainland China excluding Hubei province, to account for the regional differences in epidemic timing and potential transmissibility. We estimated the basic reproductive number $R_{0}$, corresponding to the average number of secondary infections from one case at the start of the outbreak, using the formula $1 / \mathrm{M}(-\mathrm{r})$ [9], where $\mathrm{r}$ was the growth rate and $M($.$) was the moment generating function of the generation time distribution. We$ assumed the generation time distribution followed the same gamma distribution as a previously estimated serial interval distribution with mean 7.5 days and standard 
medRxiv preprint doi: https://doi.org/10.1101/2020.03.23.20041319; this version posted March 27, 2020. The copyright holder for this preprint (which was not certified by peer review) is the author/funder, who has granted medRxiv a license to display the preprint in perpetuity.

It is made available under a CC-BY-ND 4.0 International license .

deviation 3.4 days [8]. We conducted a sensitivity analysis allowing backfill for up to 15 days prior to each change in case definitions.

To account for the uncertainty in estimates of the onset-to-reporting interval, and to allow us to quantify the uncertainty in model parameters including the growth rates, we performed our analysis in a Bayesian framework and constructed a Markov Chain Monte Carlo algorithm [10] that allowed joint parameter estimation. All statistical analyses were conducted using R version 3.5.2 (R Foundation for Statistical Computing, Vienna, Austria).

\section{RESULTS}

Prior to January 15 we were unable to identify the case definition that was used in Wuhan to identify the earliest 41 confirmed cases. The first national guideline for diagnosis and treatment was issued on 15 January, and required six specific criteria to be met for a patient to be a confirmed case of COVID-19 (Table 1, Figure 1). Notably, patients needed to have an epidemiological link to Wuhan or a wet market in Wuhan and had to fulfil four clinical conditions indicative of viral pneumonia to be identified as suspected cases, and then had to have a respiratory specimen tested by full genome sequencing that showed a close homology with SARS-CoV-2 for the final confirmation of COVID-19. In the following days and weeks, a number of revisions were made to the case definitions, allowing gradually greater sensitivity in the criteria required for case confirmation (Figure 1).

The second edition of the case definitions removed the requirement for failure of antibiotic treatment, and allowed PCR confirmation in addition to whole genome 
sequencing. The third edition modified and clarified the definitions of "severe" and "critical" cases (not discussed further, here). The fourth edition allowed patients to have an epidemiological link to other areas with reported cases, instead of being restricted to Wuhan, and suspected cases required only two instead of all the three types of clinical manifestations in addition to an epidemiological link. Perhaps the greatest change was in the fifth edition, which introduced a new category of cases specifically for Hubei province which is the epicenter of the outbreak and had the largest number of cases identified in the country. Here, "clinically confirmed" cases were patients that met clinical criteria and had radiological evidence of pneumonia with or without certain epidemiological link but did not need to have a virological confirmation of infection. In the sixth edition, this criteria was removed and no distinction was made between cases inside or outside Hubei province. In the seventh edition, serology was added as an additional option for laboratory confirmation.

We modelled the effects of changes in case definition from version 1 to version 2 , from version 2 to 4 , and from version 4 to 5 . We did not explore the effects of changing from version 2 to 3 since version 3 only included updates to the severity classifications. We were not able to explore the change after version 5 since we only analysed data up to 20 February which included just the first two days after the release of version 6 . We were not able to find information on incidence of cases by illness onset date after February 20 and had to censor our analysis at that point.

The changes in case definitions had a clear impact on the proportion of infections that were identified and counted as confirmed cases. As of February 20, there were 55,508 confirmed cases in China, among which $26,927,15,847$ and 12,734 were from Wuhan, 
medRxiv preprint doi: https://doi.org/10.1101/2020.03.23.20041319; this version posted March 27, 2020. The copyright holder for this preprint (which was not certified by peer review) is the author/funder, who has granted medRxiv a license to display the preprint in perpetuity.

It is made available under a CC-BY-ND 4.0 International license .

Hubei province excluding Wuhan, and China excluding Hubei province, respectively. We estimated that the mean onset-to-reporting delay was 8.6 days (95\% CI: 7.4, 10.1) and the $95^{\text {th }}$ percentile of this distribution was 15.7 days (95\% CI: 13.0, 20.1). Allowing for a 10 day backfill of cases, we estimated that when the case definitions were changed from version 1 to 2 , version 2 to 4 and version 4 to 5 , the proportion of infections being identified as COVID-19 cases were increased by 7.1-fold (95\% credible interval (CI): 4.8, 10.9), 2.8-fold (95\% CI: 1.9, 4.2) and 4.2-fold (95\% CI: 2.6, 7.3) respectively (Figure 2).

In a hypothetical analysis assuming that the case definitions from version 5 had been applied throughout the outbreak, and that laboratory testing with RT-PCR had been available from an early stage of the epidemic, we estimated that 232,000 (95\% CI: $161,000,359,000$ ) cases would have met the case definition and could have been detected by February 20, of which 127,000 (95\% CI: 86,000, 198,000), 55,000 (95\% CI: $38,000,86,000)$ and $50,000(95 \%$ CI: 34,000, 78,000) cases were from Wuhan, Hubei excluding Wuhan, and China excluding Hubei respectively (Figure 3). In this same hypothetical analysis, among the 127,000 cases that we estimated in Wuhan by February 20, we estimated that there would have been 11,000 infections ( $95 \% \mathrm{CI}$ : $7,000,21,000$ ) that met version 5 of the case definition with illness onset by January 1 , 2020. In the observed data, there were 114 confirmed COVID-19 cases with illness onset by January 1,2020 , corresponding to around $1 \%$ of our estimated total. Prior January 23, we estimated that $92 \%$ (95\% CrI: 88\%, 95\%) cases were undetected.

We estimated that after implementation of control measures on January 23 the growth rate declined substantially to below zero, from 0.08 to -0.15 in Wuhan which was a change of -0.23 (95\% CI: $-0.27,-0.20$ ). The corresponding changes in growth rate were - 
medRxiv preprint doi: https://doi.org/10.1101/2020.03.23.20041319; this version posted March 27, 2020. The copyright holder for this preprint (which was not certified by peer review) is the author/funder, who has granted medRxiv a license to display the preprint in perpetuity.

It is made available under a CC-BY-ND 4.0 International license .

0.26 (95\% CI: $-0.30,-0.22)$ and -0.28 (95\% CI: $-0.32,-0.25)$ for Wuhan, Hubei excluding Wuhan, and for China excluding Hubei province, respectively. This suggested that the control measures were very effective, reducing the effective reproductive number to well below one.

After adjusting for the changes in case definitions, we estimated that the epidemic growth rate before January 23 was around 0.08 to 0.10 and the doubling time was around 7.0 to 8.7 days for these three geographic areas, and the differences among them were not statistically significant (Table 2). If instead the change in case definitions was unaccounted for, the growth rate would have been substantially overestimated and the doubling time would have been substantially underestimated (Table 2). Using a growth rate of $0.08-0.10$ with a mean serial interval of 7.5 days [8] would lead to $R_{0}$ estimates in the range 1.8-2.0. If we instead used the erroneous growth rate estimates of 0.15-0.19 (Table 2) we would obtain $R_{0}$ estimates in the range of 2.8-3.5.

In a sensitivity analysis allowing for 15 days of backfill each time the case definition changed, the proportion of infections being identified as COVID-19 cases were increased by 3.0 -fold to 8.8 -fold. We estimated that 253,000 (95\% CI: $158,000,436,000$ ) cases would have met the case definition and could have been detected by February 20. These estimates were slightly higher but as expected given the backfill period was longer.

\section{DISCUSSION}

We found that changes in case definitions of COVID-19 in China led to stepwise increases in the proportion of all infections identified as cases, by 7.1-fold, 2.8-fold and 4.2-fold with updates to versions 2, 4 and 5 of the case definitions, respectively. Overall, 
we estimated that around 232,000 cases could have been confirmed in the first wave of COVID-19 in China by late February 2020 if, hypothetically, version 5 of the case definitions had been used throughout. Certainly, the number of infected persons is likely to be greater than 232,000 because many mild cases were not tested or confirmed, and some infections were asymptomatic [11]. We estimated that many cases were undetected when using earlier case definition, which is consistent with another recent study which estimated that around $85 \%$ cases were undetected prior to January 23, when case definition 2 was used [12].

The introduction of "clinically confirmed" cases in the fifth edition of the case definitions allowed a large number of highly suspected cases who could not receive a virologic test to be isolated and treated in time and reallocation of laboratory testing resources to be used for identifying and then isolating cases in the community as part of the containment efforts. This category was removed within a week, in the sixth edition of case definitions (Table 1) as explained by health officials that laboratory testing was sufficient to confirm all cases and the "clinically confirmed" category was unnecessary [13]. However confirmation of viral pneumonia with radiological evidence could be an important alternative for diagnosis and surveillance of COVID-19 in locations with limited laboratory testing capacity, and would also be a good option if or when a surge in COVID-19 consultations exceeds local laboratory capacity. This could be combined with testing a portion of the clinical confirmed cases to correct the actual case numbers afterward [14].

Case definitions are often developed for outbreak investigations in which the objective is to identify the source of infections [15] while only later if an epidemic occurs are case 
definitions used for surveillance. In the case of the COVID-19 epidemic in China, the initial case definitions for COVID-19 allowed investigation of potential animal exposures and infections epidemiologically linked with the epicentre, Wuhan, but might not capture cases linked with wider areas potentially affected by COVID-19 [16]. Similarly, the earlier case definitions had more specific requirements for clinical manifestations given the limited knowledge of the novel virus, leading to a low sensitivity for case identification including an under-detection of milder infections $[16,17]$. As the evidence of the clinical spectrum of COVID-19 became available the case definition was rightly updated to account for this.

However, our analysis demonstrated that estimates of key epidemiological parameters using epidemic curves could be very biased if they do not account for such changes in case definitions. Specifically, we found that if we had estimated the exponential growth in the epidemic curve without accounting for the changes in case definitions, we would have substantially overestimated the growth rate and substantially underestimated the doubling time (Table 2). There are a number of high estimates of growth rates and $R_{0}$ in the grey literature on preprint servers, some of which might suffer from this particular bias $[18,19]$. Other high estimates of growth rates or $R_{0}$ based on epidemic curves by reporting date might have overestimated transmissibility because of the shortening in onset-to-reporting delays as the epidemic progressed.

Our findings also suggest caution may be needed for analyses of the trajectories of epidemic curves elsewhere. Epidemics could appear to be growing faster than they actually are, because of rapid expansions in testing practices. The availability of and resolve for laboratory testing will also be a major factor shaping epidemic curves [20], 
which will be important to guide the public health responses. Due to the limited capacity for confirmation tests, Switzerland has announced it would stop testing mild cases and restrict such to those who are more ill [21], and other countries may adopt the same approach as case numbers increase. As discussed above, radiological confirmation could be a potential alternative to track the incidence of hospitalised cases.

A limitation of our study is that we did not formulate an individual-based mechanistic transmission model, but used a simple model with exponential growth and then exponential decay (Figure 2). Further work could explore more complex dynamic models, allowing for the marginal effects of different types of interventions that were introduced at different times towards the end of January 2020, in addition to accounting for the changes in case definitions. Analyses of the effects of interventions in China should be evaluated carefully if they do not account for the changes in case definitions. Second, we were only able to collect the data for the epidemic curve up to February 20, 2020 from published information. Therefore, we cannot evaluate the impact of changes in the case definition from version 5 to 6 and from version 6 to 7 , although case numbers have been substantially declined after February 20 .

In conclusion, we have shown that changes in case definitions had a very substantial effect on the proportion of all infections identified as cases as time progressed, and therefore also had a very substantial effect on the epidemic curve. Ignoring those changes would have led to biased estimates of some key epidemiological parameters. We estimated that there could have been 232,000 cases by February 20 if, hypothetically, version 5 of the case definitions had been used throughout the epidemic. 
medRxiv preprint doi: https://doi.org/10.1101/2020.03.23.20041319; this version posted March 27, 2020. The copyright holder for this preprint (which was not certified by peer review) is the author/funder, who has granted medRxiv a license to display the preprint in perpetuity. It is made available under a CC-BY-ND 4.0 International license.

However this would be an underestimate of the number of infections up to that point because it would not have captured some mild or asymptomatic cases. Serological studies could be used to reveal the true cumulative incidence of infections. 
medRxiv preprint doi: https://doi.org/10.1101/2020.03.23.20041319; this version posted March 27, 2020. The copyright holder for this preprint (which was not certified by peer review) is the author/funder, who has granted medRxiv a license to display the preprint in perpetuity.

It is made available under a CC-BY-ND 4.0 International license .

\section{REFERENCES}

1. Gregg MB. Field Epidemiology. New York: Oxford University Press; 2002.

2. Zhu N, Zhang D, Wang W, Li X, Yang B, Song J, et al. A Novel Coronavirus from

Patients with Pneumonia in China, 2019. N Engl J Med. 2020;382(8):727-33. Epub

2020/01/25. doi: 10.1056/NEJMoa2001017. PubMed PMID: 31978945.

3. Wuhan Municipal Health Commission. Report on unexplained viral pneumonia. 5 Jan 2020. Accessed 12 Mar 2020. Chinese. Available from:

http://wjw.wuhan.gov.cn/front/web/showDetail/2020010509020.

4. Wu P, Hao X, Lau EHY, Wong JY, Leung KSM, Wu JT, et al. Real-time tentative assessment of the epidemiological characteristics of novel coronavirus infections in Wuhan, China, as at 22 January 2020. Euro Surveill. 2020;25(3). doi: 10.2807/1560-

7917.ES.2020.25.3.2000044. PubMed PMID: 31992388; PubMed Central PMCID:

PMCPMC6988272.

5. National Health Commission of the People's Republic of China. Release of 7th edition of case defintions. 3 Mar 2020. Accessed 12 Mar 2020. Chinese. Available from: http://www.nhc.gov.cn/yzygj/s7653p/202003/46c9294a7dfe4cef80dc7f5912eb1989. $\underline{\text { shtml. }}$

6. World Health Organization. Report of the WHO-China Joint Mission on Coronavirus Disease 2019 (COVID-19). 24 Feb 2020. Accessed 12 Mar 2020. Available from:

https://www.who.int/docs/default-source/coronaviruse/who-china-joint-mission-oncovid-19-final-report.pdf.

7. Wu JT, Leung K, Leung GM. Nowcasting and forecasting the potential domestic and international spread of the 2019-nCoV outbreak originating in Wuhan, China: a modelling study. Lancet. 2020;395(10225):689-97. doi: 10.1016/S0140-6736(20)30260-9. PubMed

PMID: 32014114. 
medRxiv preprint doi: https://doi.org/10.1101/2020.03.23.20041319; this version posted March 27, 2020. The copyright holder for this preprint (which was not certified by peer review) is the author/funder, who has granted medRxiv a license to display the preprint in perpetuity.

It is made available under a CC-BY-ND 4.0 International license .

8. Li Q, Guan X, Wu P, Wang X, Zhou L, Tong Y, et al. Early Transmission Dynamics in Wuhan, China, of Novel Coronavirus-Infected Pneumonia. N Engl J Med. 2020. doi: 10.1056/NEJMoa2001316. PubMed PMID: 31995857.

9. Wallinga J, Lipsitch M. How generation intervals shape the relationship between growth rates and reproductive numbers. Proc Biol Sci. 2007;274(1609):599-604. Epub 2007/05/04. doi: 10.1098/rspb.2006.3754. PubMed PMID: 17476782; PubMed Central PMCID: PMCPMC1766383.

10. Gilks WR, Richardson S, Spiegelhalter D. Markov Chain Monte Carlo in Practice. London: Chapman \& Hall; 1996.

11. The Novel Coronavirus Pneumonia Emergency Response Epidemiology Team. The Epidemiological Characteristics of an Outbreak of 2019 Novel Coronavirus Diseases (COVID-19) - China, 2020. China CDC Weekly. 2020.

12. Li R, Pei S, Chen B, Song Y, Zhang T, Yang W, et al. Substantial undocumented infection facilitates the rapid dissemination of novel coronavirus (SARS-CoV2). Science. 2020:eabb3221.

13. CRJ online. The capacity of PCR testing in Hubei has been increased. 21 Feb 2020. Accessed 12 Mar 2020. Chinese. Available from: http://news.cri.cn/20200221/1f2057ea-de3b-707b-bfdc-e467ef7a596d.html.

14. Lipsitch M, Hayden FG, Cowling BJ, Leung GM. How to maintain surveillance for novel influenza A H1N1 when there are too many cases to count. Lancet. 2009;374(9696):1209-11. doi: 10.1016/S0140-6736(09)61377-5. PubMed PMID: 19679345. 15. United States Centers for Disease Control and Prevention. Principles of Epidemiology in Public Health Practice (https://www.cdc.gov/csels/dsepd/ss1978/index.html)2011. 
medRxiv preprint doi: https://doi.org/10.1101/2020.03.23.20041319; this version posted March 27, 2020. The copyright holder for this preprint (which was not certified by peer review) is the author/funder, who has granted medRxiv a license to display the preprint in perpetuity.

It is made available under a CC-BY-ND 4.0 International license .

16. Huang C, Wang Y, Li X, Ren L, Zhao J, Hu Y, et al. Clinical features of patients infected with 2019 novel coronavirus in Wuhan, China. Lancet. 2020;395(10223):497-506. doi: 10.1016/S0140-6736(20)30183-5. PubMed PMID: 31986264.

17. Wu Z, McGoogan JM. Characteristics of and Important Lessons From the Coronavirus Disease 2019 (COVID-19) Outbreak in China: Summary of a Report of 72314 Cases From the Chinese Center for Disease Control and Prevention. JAMA. 2020. doi: 10.1001/jama.2020.2648. PubMed PMID: 32091533.

18. Liu T, Hu J, Kang M, Lin L, Zhong H, Xiao J, et al. Transmission dynamics of 2019 novel coronavirus (2019-nCoV). Biorxiv. 2020. doi:

https://doi.org/10.1101/2020.01.25.919787. PubMed PMID: 32014114.

19. Zhao S, Lin Q, Ran J, Musa SS, Yang G, Wang W, et al. Preliminary estimation of the basic reproduction number of novel coronavirus (2019-nCoV) in China, from 2019 to 2020: A data-driven analysis in the early phase of the outbreak. Int J Infect Dis. 2020;92:2147. doi: 10.1016/j.ijid.2020.01.050. PubMed PMID: 32007643.

20. Lipsitch M, Swerdlow DL, Finelli L. Defining the Epidemiology of Covid-19 Studies Needed. N Engl J Med. 2020. doi: 10.1056/NEJMp2002125. PubMed PMID: 32074416.

21. CNNMoney Switzerland. Why You Can’t Trust Coronavirus Counts. 10 Mar 2020. Accessed 12 Mar 2020. Available from: https://www.cnnmoney.ch/shows/bigpicture/videos/coronavirus-count-switzerland. 
medRxiv preprint doi: https://doi.org/10.1101/2020.03.23.20041319; this version posted March 27, 2020. The copyright holder for this preprint (which was not certified by peer review) is the author/funder, who has granted medRxiv a license to display the preprint in perpetuity. It is made available under a CC-BY-ND 4.0 International license.

\section{ACKNOWLEDGMENTS}

The authors thank Julie Au for administrative support

\section{FUNDING}

This project was supported by a commissioned grant from the Health and Medical

Research Fund, Food and Health Bureau, Government of the Hong Kong Special

Administrative Region.

\section{POTENTIAL CONFLICTS OF INTEREST}

BJC reports honoraria from Sanofi Pasteur and Roche. The authors report no other potential conflicts of interest. 


\section{FIGURE LEGENDS}

Figure 1: Evolution of the case definitions of COVID-19 in seven editions of the National Guideline for Diagnosis and Treatment of COVID-19 in mainland China since 15 January 2020.

Figure 2: Number of reported COVID-19 cases by date of onset and the estimated daily numbers of cases in the hypothetical analyses by assuming a version of case definitions to be applied throughout the study period in mainland China, as of 20 February 2020. Symbols show daily numbers of cases reported, and colours indicated reported cases (symbols) or estimated cases (lines) at different time periods in line with the timeline when different versions of COVID-19 case definitions were released. The color for changing case definitions was adjusted earlier to reflect that assumption that there was a backfill of symptomatic cases who had not yet presented for diagnosis up to 10 days before each change in case definition, and therefore the effect of changing case definition would appear to modify the proportion of infections captured as cases before the actual day of change.

Figure 3: Observed (blue bars) and augmented occurrence by different case definition (red bars by case definition version 2, yellow bars by case definition version 4 and grey bars by case definition version 5) of COVID-19 cases by date of illness onset in Wuhan (Panel A), Hubei province excluding Wuhan (Panel B) and other provinces in mainland China excluding Hubei province (Panel C). 
Table 1. Definitions of suspected and confirmed cases of COVID-19 in seven versions of the National Guideline for Diagnosis and

Treatment of the Novel Coronavirus Infection implemented in China since 15 January 2020.

\begin{tabular}{|c|c|c|c|c|}
\hline $\begin{array}{l}\text { Version of } \\
\text { guideline }\end{array}$ & Case definitions & $\begin{array}{l}\text { Difference from the previous } \\
\text { version }\end{array}$ & $\begin{array}{l}\text { Date of } \\
\text { issue }\end{array}$ & $\begin{array}{l}\text { Date of } \\
\text { online } \\
\text { publication* }\end{array}$ \\
\hline 1 & $\begin{array}{l}\text { Medically observed case: } \\
\text { Meet one of the epidemiological criteria and all the clinical manifestations below: } \\
\text { 1. Epidemiological history: } \\
\text { (1) Travelled to Wuhan within two weeks before illness onset } \\
\text { (2) Had direct/indirect exposure to markets (especially wet markets) in Wuhan within } \\
\text { two weeks before illness onset. } \\
\text { 2. Clinical manifestations: } \\
\text { (1) Fever; } \\
\text { (2) Pneumonia indicated by chest radiograph; } \\
\text { (3) Reduced or normal white blood cell count, or reduced lymphocyte count during the } \\
\text { early stage of the illness; } \\
\text { (4) After initiation of a standard antimicrobial treatment (following the "Guidelines for } \\
\text { the Diagnosis and Treatment of Community-acquired Pneumonia in Chin ese Adults } \\
\text { (2016 Edition)" issued by Chinese Thoracic Society and the "Guidelines for the Diagnosis } \\
\text { and Treatment of Community-acquired Pneumonia in Children (2019 Edition)" issued } \\
\text { by National Health Commission) for } 3 \text { days, the patient's clinical conditions had not been } \\
\text { significantly improved or become deteriorated. } \\
\text { Confirmed case: } \\
\text { A medically observed case has viruses isolated from respiratory specimens (sputum, } \\
\text { throat swab, etc.) showing high toto a known novel coronavirus by the whole genome } \\
\text { sequencing. }\end{array}$ & NA & Jan 15 & $\begin{array}{l}\text { Not } \\
\text { published } \\
\text { online }\end{array}$ \\
\hline 2 & $\begin{array}{l}\text { Suspected case (previously named medically observed case): } \\
\text { Meet one of the epidemiological criteria and all the clinical manifestations below: } \\
\text { 1. Epidemiological history } \\
\text { (1) travelled to or had lived in Wuhan within two weeks before illness onset; } \\
\text { (2) had a contact within } 14 \text { days before onset with a person showing fever and } \\
\text { respiratory symptoms from Wuhan; }\end{array}$ & $\begin{array}{l}\text { 1. Medically observed cases were } \\
\text { renamed as suspected cases; } \\
\text { 2. Removed an exposure to markets } \\
\text { in Wuhan from the epidemiological } \\
\text { criteria. } \\
\text { 3. Added contact with symptomatic }\end{array}$ & Jan 18 & $\begin{array}{l}\text { Not } \\
\text { published } \\
\text { online }\end{array}$ \\
\hline
\end{tabular}




\begin{tabular}{|c|c|c|c|c|}
\hline & $\begin{array}{l}\text { (3) had a clustering occurrence. } \\
\text { 2. Clinical manifestations: } \\
\text { (1) Fever; } \\
\text { (2) Pneumonia indicated by chest radiograph; } \\
\text { (3) Reduced or normal white blood cell count, or reduced lymphocyte count during early } \\
\text { onset; } \\
\text { Confirmed case: } \\
\text { A suspected case has a detection of nucleic acid of the novel coronavirus from } \\
\text { respiratory specimens including sputum, throat swab or lower respiratory tract } \\
\text { specimens using the real-time fluorescent RT-PCR to test; or has isolated viruses } \\
\text { showing high homology with a known SARS-CoV-2 by the whole genome sequencing. }\end{array}$ & $\begin{array}{l}\text { persons from Wuhan as one of the } \\
\text { epidemiological criteria; } \\
4 \text {. Added clustering occurrence as } \\
\text { one of the epidemiological criteria; } \\
\text { 5. Removed failure in antibiotic } \\
\text { treatment from the clinical } \\
\text { manifestations; } \\
\text { 6. Added RT-PCR as a laboratory } \\
\text { test to confirm the infection of } \\
\text { SARS-CoV-2. }\end{array}$ & & \\
\hline 3 & $\begin{array}{l}\text { Suspected case (previously named medically observed case): } \\
\text { Meet one of the epidemiological criteria and all the clinical manifestations below: } \\
\text { 1. Epidemiological history: } \\
\text { (1) travelled to or had lived in Wuhan within } 2 \text { weeks before illness onset; } \\
\text { (2) had contacted patients from Wuhan who had fever and respiratory symptoms within } \\
\text { 14 days before onset; } \\
\text { (3) had a clustering occurrence. } \\
\text { 2. Clinical manifestations: } \\
\text { (1) Fever; } \\
\text { (2) Pneumonia indicated by chest radiograph; } \\
\text { (3) Low or normal white blood cell count, or low lymphocyte count during early onset; } \\
\text { Confirmed case: } \\
\text { A suspected case has a detection of nucleic acid of the novel coronavirus from } \\
\text { respiratory specimens including sputum, throat swab or lower respiratory tract } \\
\text { specimens using the real-time fluorescent RT-PCR to test; or has isolated viruses } \\
\text { showing high homology with a known SARS-CoV-2 by the whole genome sequencing. }\end{array}$ & $\begin{array}{l}\text { No difference in definitions for } \\
\text { suspected and confirmed cases }\end{array}$ & $\operatorname{Jan} 22$ & Jan 23 \\
\hline 4 & $\begin{array}{l}\text { Suspected case: } \\
\text { Meet one of the epidemiological criteria AND two of the clinical manifestations: } \\
\text { 1. Epidemiological history: } \\
\text { (1) travelled to or had lived in Wuhan or other areas with sustained local transmission } \\
\text { of COVID-19 within } 14 \text { days before illness onset; }\end{array}$ & $\begin{array}{l}\text { 1. Expanded the epidemiological } \\
\text { criteria by adding travel history to } \\
\text { or residence in other areas than } \\
\text { Wuhan having sustained local } \\
\text { transmission of COVID-19 within } 14\end{array}$ & Jan 27 & $\begin{array}{l}\text { Jan } 27 \text { on the } \\
\text { NHC website } \\
\text { and Jan } 28 \\
\text { on Chinese } \\
\text { CDC website }\end{array}$ \\
\hline
\end{tabular}




\begin{tabular}{|c|c|c|c|c|}
\hline & $\begin{array}{l}\text { (2) Contacted with patient(s) with fever or respiratory symptoms from Wuhan or other } \\
\text { areas with sustained local transmission of COVID-19 within } 14 \text { days before illness onset; } \\
\text { (3) Had clustering occurrence, or epidemiologically linked to people infected with the } \\
\text { SARS-CoV-2. } \\
\text { 2. Clinical manifestations: } \\
\text { (1) Fever; } \\
\text { (2) Pneumonia indicated by chest radiograph; } \\
\text { (3) Low or normal white blood cell count, or low lymphocyte count during early onset; } \\
\text { Confirmed case: } \\
\text { A suspected case with one of the following etiological confirmations: } \\
\text { 1. Respiratory or blood specimens tested positive for the nucleic acid of SARS-CoV-2 by } \\
\text { the real-time fluorescent RT-PCR; } \\
\text { 2. Viruses isolated from respiratory or blood specimens showing high homology with a } \\
\text { known SARS-CoV-2 by whole genome sequencing. }\end{array}$ & $\begin{array}{l}\text { days before onset. } \\
\text { 2. Expanded the epidemiological } \\
\text { criteria by adding contact history } \\
\text { with persons having fever or } \\
\text { respiratory symptoms from other } \\
\text { areas thank Wuhan having } \\
\text { sustained local transmission of } \\
\text { COVID-19 within } 14 \text { days before } \\
\text { onset. } \\
\text { 3. Revised diagnosis of suspected } \\
\text { cases with } 2 \text { out of } 3 \text { clinical } \\
\text { manifestations and one } \\
\text { epidemiological criterion. } \\
\text { 4. Specified the types of specimens } \\
\text { used for laboratory tests. }\end{array}$ & & \\
\hline 5 & $\begin{array}{l}\text { Provinces outside Hubei: } \\
\text { Suspected case: } \\
\text { Meet one of the epidemiological criteria AND two of the clinical manifestations, OR meet } \\
\text { all three clinical manifestations if without epidemiological history: } \\
\text { 1. Epidemiological history: } \\
\text { (1) Travelled to or had lived in Wuhan or the surrounding areas or other communities } \\
\text { with reported COVID-19 cases within } 14 \text { days before illness onset; } \\
\text { (2) Contacted with patient(s) infected with SARS-CoV-2 (positive for SARS-CoV-2 nucleic } \\
\text { acid) within } 14 \text { days before onset; } \\
\text { (3) Contacted patients with fever or respiratory symptoms from Wuhan or the } \\
\text { surrounding areas, or from communities with reported COVID-19 cases, within } 14 \text { days } \\
\text { before illness onset; } \\
\text { (4) Had clustering occurrence. } \\
\text { 2. Clinical manifestations: } \\
\text { (1) Fever and/or respiratory symptoms; } \\
\text { (2) Pneumonia indicated by chest radiograph; } \\
\text { (3) Low or normal white blood cell count, or low lymphocyte count during early onset; } \\
\text { Confirmed case: } \\
\text { A suspected case with one of the following etiological confirmations: }\end{array}$ & $\begin{array}{l}\text { 1. Separate the case definitions for } \\
\text { Hubei province from the rest of the } \\
\text { country. } \\
\text { 2. Added a new diagnostic type of } \\
\text { cases, clinically confirmed case, } \\
\text { specifically for Hubei province. } \\
\text { 3. Added visiting/living in the } \\
\text { surrounding areas of Wuhan or } \\
\text { other areas having COVID-19 cases } \\
\text { reported within } 2 \text { weeks before } \\
\text { symptom onset as one of the } \\
\text { epidemiological criteria; } \\
\text { 4. Specified "having epidemiological } \\
\text { link with a COVID-19 patient" as } \\
\text { "contact a confirmed COVID-19 } \\
\text { patient (positive for SARS-CoV-2 } \\
\text { nucleic acid) within } 14 \text { days before } \\
\text { onset”. } \\
\text { 5. Added a suspected case being } \\
\text { diagnosed without having an } \\
\text { epidemiological criterion but }\end{array}$ & Feb 4 & Feb 5 \\
\hline
\end{tabular}




\begin{tabular}{|c|c|c|c|c|}
\hline & $\begin{array}{l}\text { 1. Respiratory or blood specimens tested positive for the nucleic acid of SARS-CoV-2 by } \\
\text { the real-time fluorescent RT-PCR; } \\
\text { 2. Viruses isolated from respiratory or blood specimens showing high homology with a } \\
\text { known SARS-CoV-2 by whole genome sequencing. } \\
\text { Hubei Province: } \\
\text { Suspected case: } \\
\text { Meet the clinical manifestations with or without an epidemiological criterion. } \\
\text { 1. Epidemiological history: } \\
\text { (1) Travelled to or had lived in Wuhan or the surrounding areas or other communities } \\
\text { with reported COVID-19 cases within } 14 \text { days before illness onset; } \\
\text { (2) Contacted with patient(s) infected with SARS-CoV-2 (positive for SARS-CoV-2 nucleic } \\
\text { acid) within } 14 \text { days before onset; } \\
\text { (3) Contacted patients with fever or respiratory symptoms from Wuhan or the } \\
\text { surrounding areas, or from communities with reported COVID-19 cases, within } 14 \text { days } \\
\text { before illness onset; } \\
\text { (4) Had clustering occurrence. } \\
\text { 2. Clinical manifestations: } \\
\text { (1) Fever and/or respiratory symptoms; } \\
\text { (2) Low or normal white blood cell count, or low lymphocyte count during early onset. } \\
\text { Clinically diagnosed case: } \\
\text { A suspected case with pneumonia indicated by chest radiograph. } \\
\text { Confirmed case: } \\
\text { A clinically diagnosed case or suspected case with one of the following etiological } \\
\text { confirmations: } \\
\text { 1. Respiratory or blood specimens tested positive for the nucleic acid of SARS-CoV-2 by } \\
\text { the real-time fluorescent RT-PCR; } \\
\text { 2. Viruses isolated from respiratory or blood specimens showing high homology with a } \\
\text { known SARS-CoV-2 by whole genome sequencing. }\end{array}$ & $\begin{array}{l}\text { fulfilling all three clinical criteria for } \\
\text { patients outside of Hubei province. } \\
6 \text {. Suspected cases in Hubei province } \\
\text { could be diagnosed with only } 2 \text { of } \\
\text { the clinical manifestations if without } \\
\text { any epidemiological link while in } \\
\text { other provinces a suspected cases } \\
\text { had to fulfil } 3 \text { clinical criteria if } \\
\text { without an epidemiological link. }\end{array}$ & & \\
\hline 6 & $\begin{array}{l}\text { Suspected case: } \\
\text { Meet one of the epidemiological criteria AND two of the clinical manifestations, OR meet } \\
\text { all three clinical manifestations if without epidemiological history: } \\
\text { 1. Epidemiological history: } \\
\text { (1) Travelled to or had lived in Wuhan or the surrounding areas or other communities }\end{array}$ & $\begin{array}{l}\text { 1. Unified the case definitions for } \\
\text { Hubei and other provinces by } \\
\text { removing the clinically diagnosed } \\
\text { case; } \\
\text { 2. Provided suggestions that sputum }\end{array}$ & Feb 18 & Feb 19 \\
\hline
\end{tabular}




\begin{tabular}{|c|c|c|c|c|}
\hline & $\begin{array}{l}\text { with reported COVID-19 cases within } 14 \text { days before illness onset; } \\
\text { (2) Contacted with patient(s) infected with SARS-CoV-2 (positive for SARS-CoV-2 nucleic } \\
\text { acid) within } 14 \text { days before onset; } \\
\text { (3) Contacted patients with fever or respiratory symptoms from Wuhan or the } \\
\text { surrounding areas, or from communities with reported COVID-19 cases, within } 14 \text { days } \\
\text { before illness onset; } \\
\text { (4) Had clustering occurrence. } \\
\text { 2. Clinical manifestations: } \\
\text { (1) Fever and/or respiratory symptoms; } \\
\text { (2) Pneumonia indicated by chest radiograph; } \\
\text { (3) Low or normal white blood cell count, or low lymphocyte count during early onset; } \\
\text { Confirmed case: } \\
\text { A suspected case with one of the following etiological confirmations: } \\
\text { 1. Respiratory or blood specimens tested positive for the nucleic acid of SARS-CoV-2 by } \\
\text { the real-time fluorescent RT-PCR; } \\
\text { 2. Viruses isolated from respiratory or blood specimens showing high homology with a } \\
\text { known SARS-CoV-2 by whole genome sequencing. }\end{array}$ & $\begin{array}{l}\text { and lower respiratory specimens } \\
\text { were preferred for PCR testing in } \\
\text { the section of Laboratory Tests } \\
\text { whereas removed the description of } \\
\text { types of specimen to be collected for } \\
\text { etiological tests in case definitions } \\
\text { for confirmed cases. }\end{array}$ & & \\
\hline 7 & $\begin{array}{l}\text { Suspected case: } \\
\text { Meet one of the epidemiological criteria AND two of the clinical manifestations, OR meet } \\
\text { all three clinical manifestations if without epidemiological history: } \\
\text { 1. Epidemiological history: } \\
\text { (1) Travelled to or had lived in Wuhan or the surrounding areas or other communities } \\
\text { with reported COVID-19 cases within } 14 \text { days before illness onset; } \\
\text { (2) Contacted with patient(s) infected with SARS-CoV-2 (positive for SARS-CoV-2 nucleic } \\
\text { acid) within } 14 \text { days before onset; } \\
\text { (3) Contacted patients with fever or respiratory symptoms from Wuhan or the } \\
\text { surrounding areas, or from communities with reported COVID-19 cases, within } 14 \text { days } \\
\text { before illness onset; } \\
\text { (4) Had clustering occurrence ( } \geq 2 \text { cases with fever and/or respiratory symptoms in a } \\
\text { small area such as a family, an office, a school class, etc., within } 2 \text { weeks). } \\
\text { 2. Clinical manifestations: } \\
\text { (1) Fever and/or respiratory symptoms; } \\
\text { (2) Pneumonia indicated by chest radiograph; } \\
\text { (3) Low or normal white blood cell count, or low lymphocyte count during early onset; }\end{array}$ & $\begin{array}{l}\text { 1. Added details to define a } \\
\text { clustering occurrence; } \\
\text { 2. Added serologic tests as one of } \\
\text { the etiological confirmation } \\
\text { approaches. }\end{array}$ & Mar 3 & $\begin{array}{l}\text { Mar } 4 \text { on } \\
\text { NHC website }\end{array}$ \\
\hline
\end{tabular}




\begin{tabular}{|l|l|l|}
\hline Confirmed case: & \\
A suspected case with one of the following etiological confirmations: & & \\
1. Respiratory or blood specimens tested positive for the nucleic acid of SARS-CoV-2 by & & \\
the real-time fluorescent RT-PCR; & & \\
2. Viruses isolated from respiratory or blood specimens showing high homology with a & & \\
known SARS-CoV-2 by whole genome sequencing; & & \\
3. Serum tested positive for SARS-CoV-2 specific IgM and IgG antibodies; the serum & & \\
SARS-CoV-2-specific IgG antibody test changed from negative (undetectable) to positive & & \\
(detectable), or the IgG antibody level is 4 times higher in the convalescent serum than & & \\
in the serum collected at the acute phase of the infection. & & \\
\hline
\end{tabular}

*online publication refers to whether the document was available on the official websites of NHC and China CDC. 
medRxiv preprint doi: https://doi.org/10.1101/2020.03.23.20041319; this version posted March 27, 2020. The copyright holder for this preprint (which was not certified by peer review) is the author/funder, who has granted medRxiv a license to display the preprint in perpetuity. It is made available under a CC-BY-ND 4.0 International license.

Table 2. Estimates of the epidemic growth rate and doubling time prior to 23 January 2020 , with or without adjustment for changes in case definitions.

\begin{tabular}{llccc}
\hline Parameter & Adjustment & Wuhan & $\begin{array}{c}\text { Hubei province } \\
\text { excluding Wuhan }\end{array}$ & $\begin{array}{c}\text { China excluding } \\
\text { Hubei province }\end{array}$ \\
\hline $\begin{array}{l}\text { Growth } \\
\text { rate, per } \\
\text { day }\end{array}$ & $\begin{array}{l}\text { With adjustment for } \\
\text { changes in case } \\
\text { definitions }\end{array}$ & $0.08(0.06,0.10)$ & $0.10(0.08,0.12)$ & $0.10(0.08,0.12)$ \\
& Without adjustment & $0.15(0.14,0.17)$ & $0.18(0.13,0.28)$ & $0.19(0.16,0.24)$ \\
& & & & \\
Doubling & With adjustment for & $8.7(7.3,10.8)$ & $7.0(5.8,8.8)$ & $7.0(5.8,8.7)$ \\
time, days & changes in case & & & \\
& definitions & & & \\
& Without adjustment & $4.5(4.1,4.8)$ & $3.9(2.4,5.3)$ & $3.6(2.9,4.3)$ \\
\hline
\end{tabular}




\section{Criteria}

Jan 15-Jan 17

Jan 18-Jan 21

Jan 22-Jan 26

$\operatorname{Jan} 27-F e b 3$

Feb 4-Feb 17

Feb 18-Mar 2

Version 6

Mar 3-now

\section{Epidemiological history}

Travel history/residence

Areas surrounding Wuhan

Other areas with reported cases

Wuhan

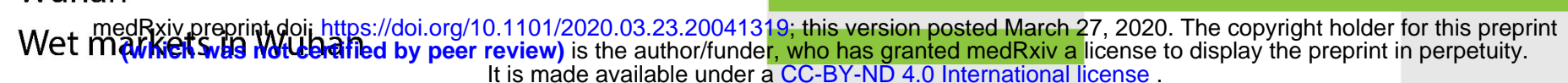

Contact with persons

With PCR confirmation of SARS-CoV-2

bWith symptoms, from areas surrounding Wuhan

bWith symptoms, from areas with reported cases

${ }^{b}$ With symptoms, from Wuhan

Occurring in a cluster

\section{Clinical manifestations}

Symptoms

Respiratory symptoms

Fever

Blood cell counts

Radiographic evidence of pneumonia

Failed antibiotic treatment

\section{Clinical tests}

Serologic evidence of infection

RT-PCR positive

Whole genome sequencing confirmed homology to SARS-CoV-2

\section{Case definitions}

Medically observed

Suspected

Clinically diagnosed

Clinically diagnosed

Confirmed
Version 1
Version 2

\section{Version 4}

\section{Fer 4 Feb}

Ver 5-Hubei
Ver 5-outside Hubei
Version 3

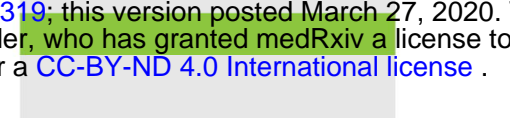

a , who has granted medrexiv a license
a

The copyright holder for this preprint
to display the preprint in perpetuity.

(n)




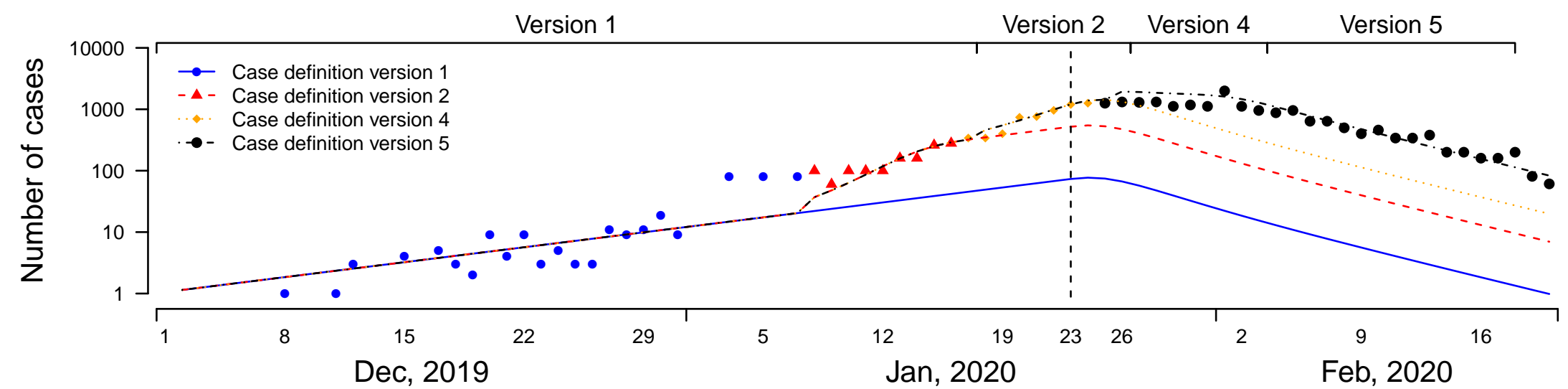

B Epidemic curve of Hubei province (excluding Wuhan)

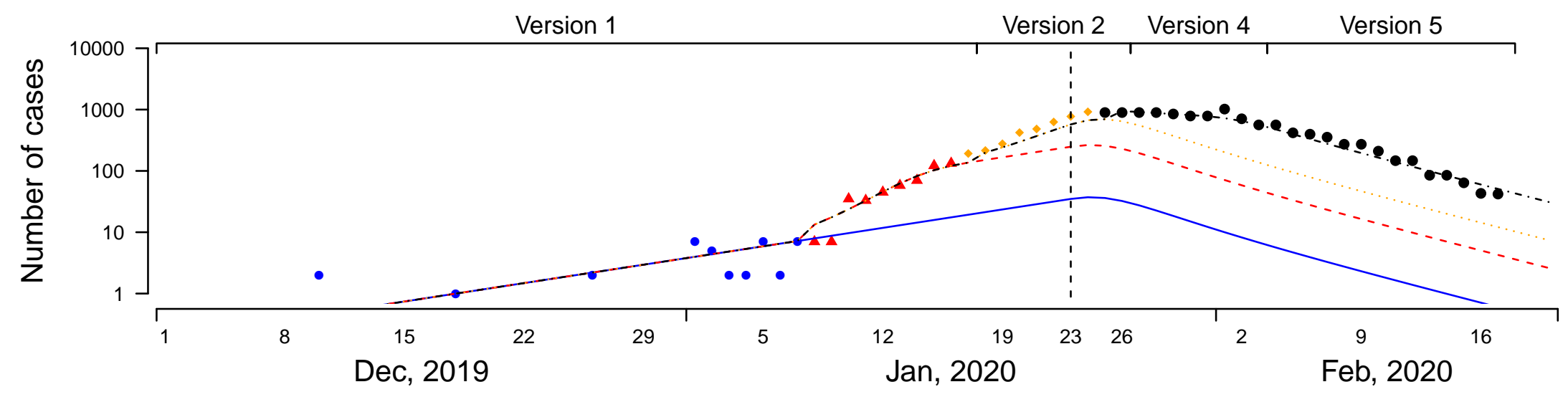

C Epidemic curve of China (excluding Hubei province)

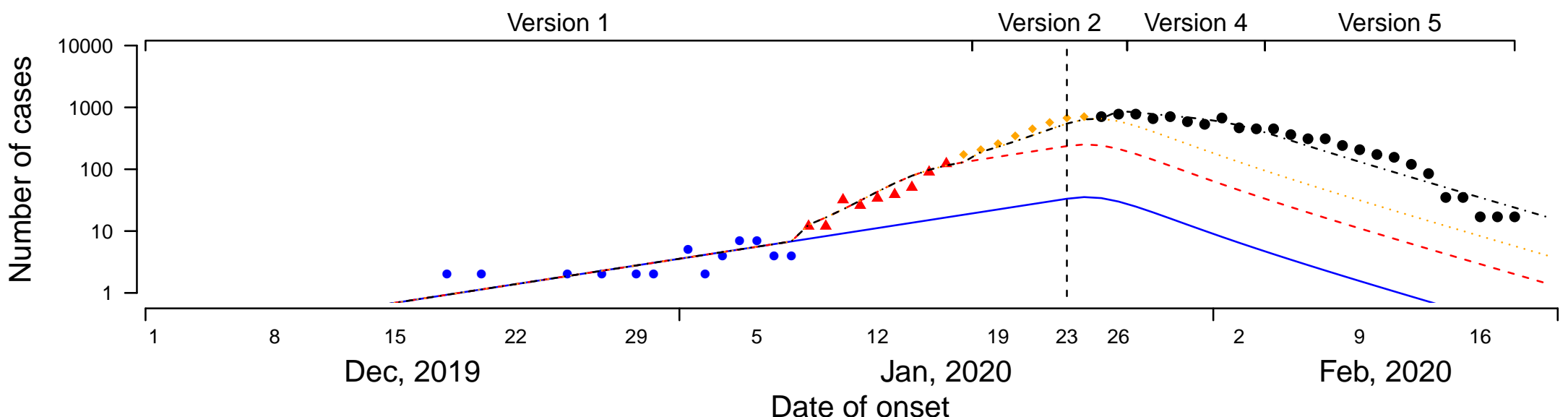




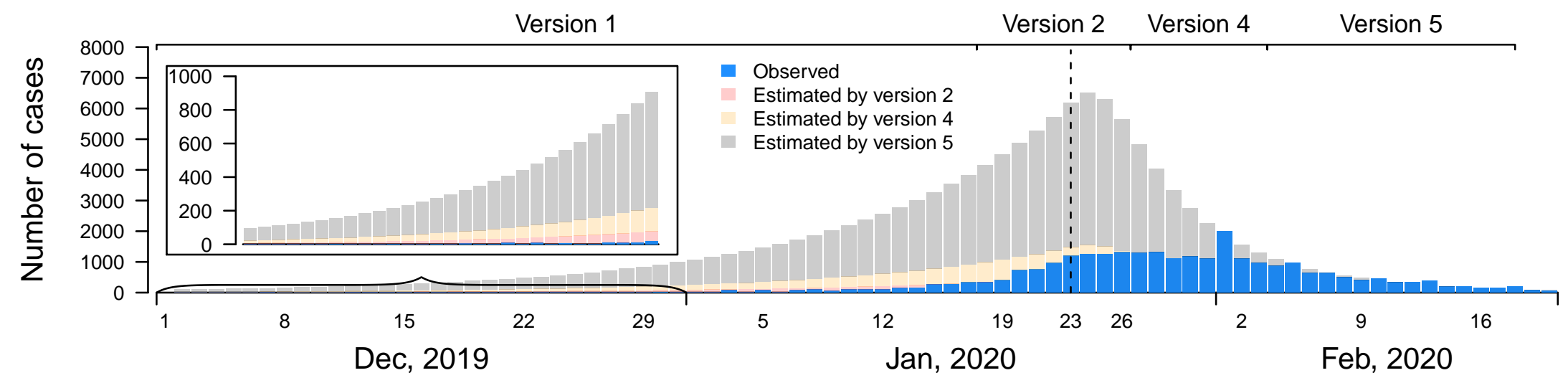

B

Epidemic curve of Hubei province (excluding Wuhan)

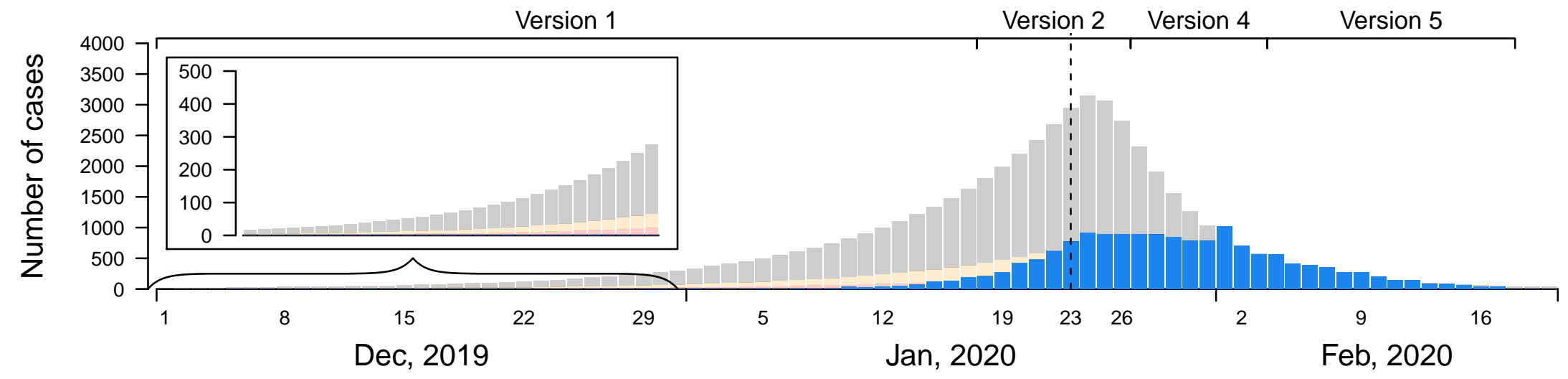

C Epidemic curve of China (excluding Hubei province)

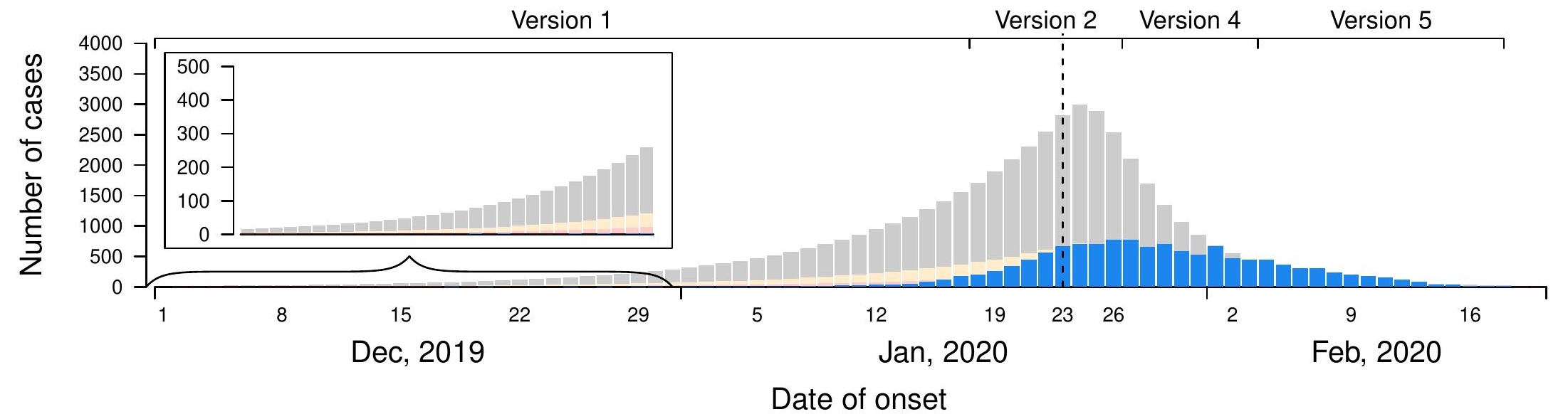

